\title{
THE PELAGONIAN NAPPE PILE IN NORTHERN GREECE AND FYROM. STRUCTURAL EVOLUTION DURING THE ALPINE OROGENY: A NEW APROACH
}

\author{
Kilias Ad. ${ }^{1}$, Frisch W. ${ }^{2}$, Avgerinas A. ${ }^{1}$, Dunkl I. ${ }^{3}$, Falalakis G. ${ }^{1}$, \\ Gawlick H-J. ${ }^{4}$ and Mountrakis D. ${ }^{1}$ \\ ${ }^{1}$ Department of Geology and Paleontology, University of Thessaloniki, GR-54124, Thessaloniki, Greece. \\ ${ }^{2}$ Instiute of Geosciences, University of Tuebingen, D-72076, Tuebingen, Germany. \\ ${ }^{3}$ Sedimentology and Enviromental Geology Geoscience center, University of Goettingen, D-37077, \\ Goettingen, Germany \\ ${ }^{4}$ Department for Applied Geosciences and Geophysics, University of Leoben, A-8700, Leoben, Austria
}

\begin{abstract}
The geometry of kinematics and the deformation history of the Pelagonian nappe pile during the Alpine orogeny have been studied in Northern Greece and FYROM. Deformation was started in Middle-Late Jurassic time and was initially associated with ocean-floor subduction followed by ophiolites obduction, nappe stacking and duplication of the Pelagonian continent. The footwall Pelagonian segment from top to bottom was metamorphosed under greenschist to amphibolit facies conditions and a relative high pressure $\left(T=450^{\circ}\right.$ to $620^{\circ} \mathrm{C}$ and $P=12,5$ to $\left.8 \mathrm{~kb}\right)$. Blueschist facies metamorphic assemblages of Late Jurassic age are immediately developed between both hangingwall and footwall Pelagonian segments. Transgressive Late Jurassic-Early Cretaceous neritic limestones and clastic sediments on the top of the obducted ophiolites are maybe related to extension and basins formation simultaneously with the nappe stacking and metamorphism at the lower structural levels of the Pelagonian nappes. Contractional tectonics and nappe stacking continued during the Albian-Aptian time. Simultaneously retrogression and pressure decreasing taken place at the tectonic lower Pelagonian footwall segment. Low grade mylonitic shear zones, possible related to extension, are developed during Late Cretaceous time simultaneously with basins formation and sedimentation of neritic Late Cretaceous to Paleocene limestones and flysch. Intense shortening and imbrication under semi-ductile to brittle conditions occurred during Paleocene to Eocene time resulting the onset of the dome like formation of the footwall Pelagonian segment. The next stages of deformation from Oligocene to Quaternary are related to brittle extension and the final uplift and configuration of the Pelagonian nappe pile.
\end{abstract}

Key words: Pelagonian nappe, Vardar/Axios Zone, compression, extension, Hellenides.

\section{Introduction-Geological setting}

While the Tertiary structural evolution of the Hellenides has been studied in detail and is satisfactorily understood (Lister et al., 1984, Sfeikos et al., 1991, Doutsos et al., 1993, Schermer 1993, Dinter and Royden 1993, Kilias et al., 1999, Xypolias et al., 2003), the geometry and kinematics of the early stages of the Alpine orogenic cycle in Jurassic and Cretaceous times still remained poorly stud- 


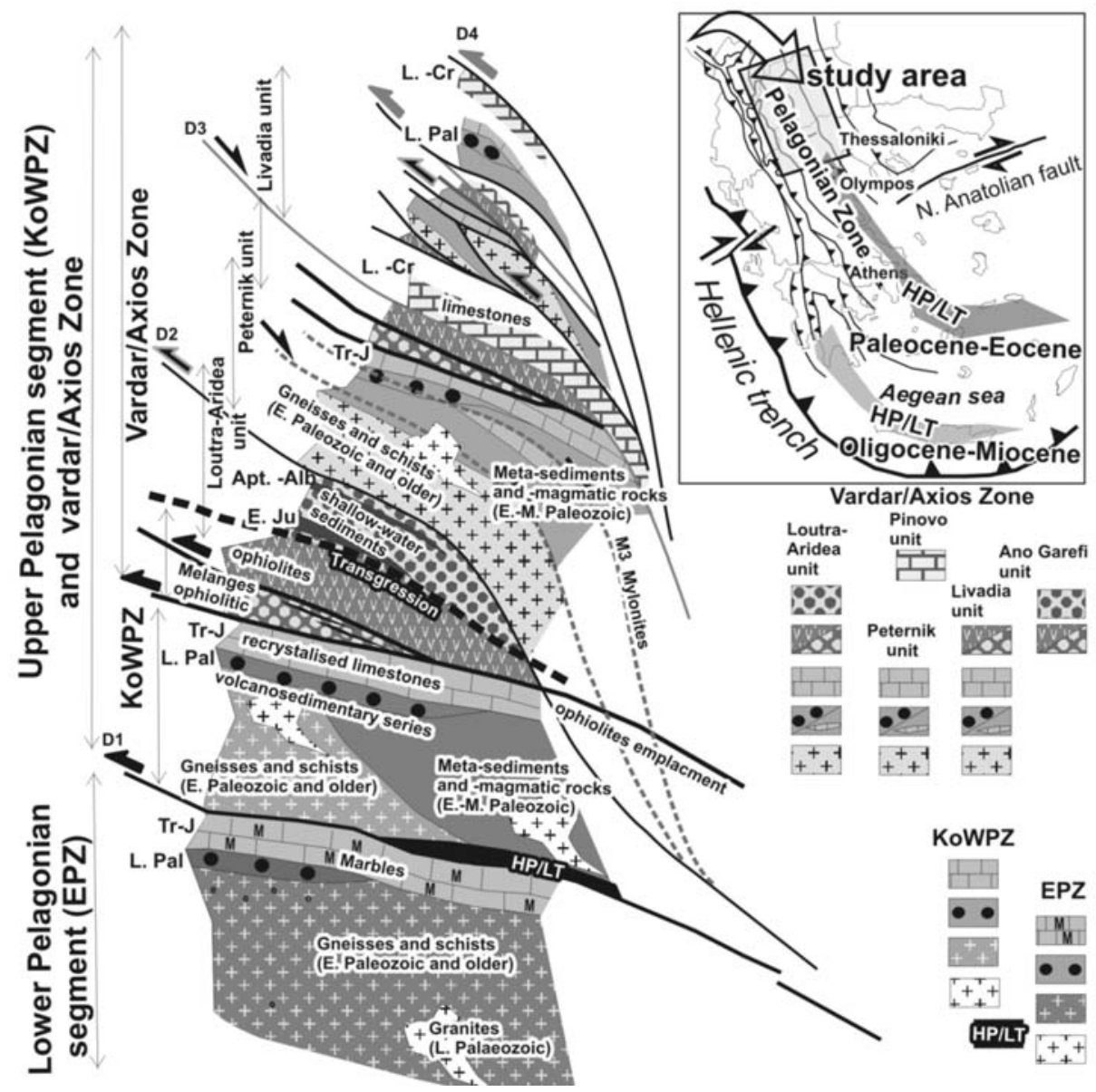

Fig. 1: Alpine architectur and structural evolution of the Pelagonian nape pile and eastern Vardar/Axios Zone.

ied and contradictory. Tertiary deformation in some cases has totally destroyed the older structures.

In order to decipher the deformational processes during the early stages of the Alpine cycle and their migration until Tertiary time, our study focused on the structurally higher Hellenides units, i. e., the Pelagonian nappes (Pelagonian Zone) and the Vardar/Axios Zone in northern Greece and the Former Yugoslavian Republic of Macedonia (FYROM) (Fig. 1,2). The timing of deformation was constrained by radiometric results mainly derived from Most (2003), stratigraphical data from Brown and Robertson (2004) and Sharp and Robertson (2006), as well as cross-cutting relationships of structures on all scales from map to thin section. P-T metamorphic conditions were estimated using metamorphic mineral assemblages and thermobarometric calculations. Shear criteria such as S-C fabrics, shear bands, asymmetric pressure shadows, mica fish, or asymmetric boudins (Simpson and Schmid 1983) have been used in order to study the kinematic history of deformation.

The Pelagonian Zone forms an elongate, NNW-SSE trending nappe pile of continental origin on the top of the External Hellenides extending from FYROM to the south through the central Greek mainland and Evvia into the Cyclades (Attico-Cycladic Massif) (Fig. 1,2). (Jacobshagen et al., 1978, 
Mountrakis 1986, Kilias et al., 1991, Doutsos et al., 1993, Schermer 1993, Avgerinas et al., 2001). A different tectono-stratigraphic subdivision is given for the Pelagonian Zone in FYROM, where the Korabi-West Pelagonian Zone (KoWPZ) is distinguished from the East Pelagonian Zone (EPZ) (Medwenitsch 1956, Arsovski \& Dumurdzanov 1984) (Fig. 1,2).

The eastern side of the Pelagonian Zone is truncated by the NNW-SSE striking Vardar/Axios Zone (Fig 2) which is particularly very well exposed in the Voras Mountains in northwestern Greece where the tectono-stratigraphic sequence can be best studied. It contains narrow belts of schists, gneisses, granitoides, Paleozoic and Mesozoic metasedimentaty rocks, Neotethyan ophiolites, transgressive Late Jurassic/Early Cretaceous and Late Cretaceous to Paleocene clastic sediments, neritic limestones and flysch (Mercier 1968, Mountrakis 1986, Galeos et al., 1994, Brown and Robertson 2004, Sharp and Robertson 2006). The complicated composition and structures of the Vardar/Axios units are given in detail in Figures 1. To the west of the Pelagonian Zone along its western fringe is evolved the Mirdita/Pindos ophiolites. There is an ongoing discussion about the displacement direction of the obducted ophiolites during Middle to Late Jurassic time on top of the Pelagonian continent, as well as the existence of one or two oceans bothsides of the Pelagonian continent (Jacobshagen et al., 1978, Vergely 1984, Mountrakis 1986, Shallo and Dileck 2003, Brown and Robertson 2004, Rassios and Moores 2006, Sharp and Robertson 2006, Gawlick et al., 2008).

In this paper we rergard the East Pelagonian Zone as an exhumed Pelagonian dome (footwall Pelagonian segment) beneath the overthrust Korabi-West Pelagonian zone (hangingwall Pelagonian segment) and the Vardar/Axios units (Fig. 2).

\section{Deformation analysis and kinematics}

The geometry and kinematics of deformation, cross cutting relationships, and the syn-kinematic growth of metamorphic mineral assemblages related to a given structure in combination with regional considerations record the progressive activity of seven $\left(\mathrm{D}_{\mathrm{HP}}\right.$ to $\left.\mathrm{D}_{6}\right)$ tectonic events from Middle Jurassic to Neogene time. They document the change from ductile conditions in the early stages of deformation to semi-ductile and eventually brittle conditions in the late stages and are related to plate convergence and the closure of the Tethyan ocean, as well as to orogenic collapse. Shortening and extension alternated.

\section{$D_{H P}$ event}

High pressure structures $\left(\mathrm{D}_{\mathrm{HP}}\right)$ are preserved at the boundary between EPZ and KoWPZ on the western limb of the East Pelagonian anticlinorium, and between EPZ and Vardar/Axios Zone at its eastern flank. $\mathrm{D}_{\mathrm{HP}}$ can be traced on top of the marble cover of the EPZ so that it surrounds the East Pelagonian antictinorium following the tectonic boundary between EPZ and the overlying KoWPZ and Vardar/Axios units (Fig. 1,2).

$\mathrm{D}_{\mathrm{HP}}$ structures are characterized by the occurrence of a relict $\mathrm{S}_{\mathrm{HP}}$ foliation associated with an about WNW-ESE trending stretching lineation $\left(\mathrm{L}_{\mathrm{HP}}\right) . \mathrm{L}_{\mathrm{HP}}$ is defined mainly by blue amphibole, white mica and chlorite. Majer and Mason (1983) report also sodic pyroxene related to the high pressure event. Syn- $\mathrm{D}_{\mathrm{HP}}$ white mica yielded K/Ar ages of ca. 150Ma (Most et al., 2001, Most 2003). $\mathrm{D}_{\mathrm{HP}}$ is related to subduction, nappe stacking and crustal thickening.

\section{$D_{1}$ event}

The $\mathrm{D}_{1}$ event records penetrative ductile structures. They are well preserved in the EPZ and along its top tectonic contact. In the KoWPZ and the Vardar/Axios basement no geochronological or strati- 


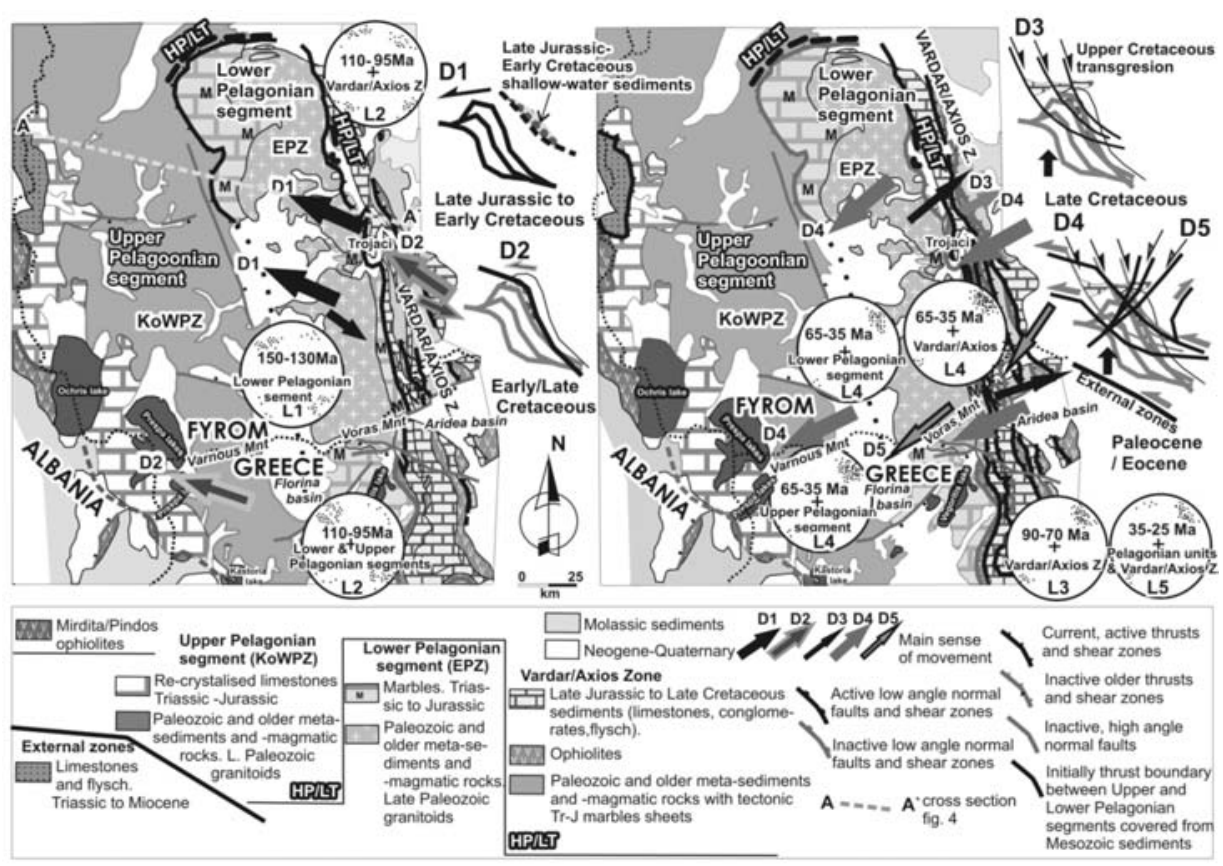

Fig. 2: Tectonic maps of the Pelagonian nape pile and the adjacent Vardar/Axios zone. The main sense of movements during the several stages of the alpine deformation is showed.

graphic data are available to document this event. D1 created a penetrative syn-metamorphic foliation $\left(\mathrm{S}_{1}\right)$ with a general NNW-SSE trend. It dips towards the WSW in the western limb of the EPZ culmination and towards the ENE in the eastern limb (Fig. 2).

$B_{1}$ folds with $S_{1}$ as axial plane foliation are scarce. Only small-scale isoclinal folds were observed (Fig. 3), sometimes also as sheath or intrafolial folds with their axis subparallel to $\mathrm{L}_{1}$. The $\mathrm{L}_{1}$ stretching lineation is well developed. Its trend appears not to be constant but mainly NW-SE to WNW-ESE (Fig. 3). NE-SW trending $\mathrm{L}_{1}$ is also observed in few cases. Chloritoid, white mica, chlorite, feldspar (K-Na-feldspars and/or plagioclase), garnet, quartz ribbons, staurolite, kyanite, and green amphibole are the most common minerals defining $\mathrm{S}_{1}$ and $\mathrm{L}_{1}$. Static recrystallisation of quartz created polygonal fabrics and indicate post-kinematic annealing.

The main direction of movement during $\mathrm{D}_{1}$ appears to be top-to-WNW or NW. In some places deviating directions have been found, e. g., towards SE (Fig. 3). Near Trojaci on the eastern flank of the EPZ, S-C fabrics related to $\mathrm{D}_{1}$ indicate WNW-ward thrusting of the Paleozoic schists of the Vardar/Axios Zone (Fig. 3). K/Ar, Ar/Ar and Rb/Sr isotopic ages on syn- $\mathrm{D}_{1}$ white mica and biotite yielded a groop of ages between 150 to 130Ma (Most et al., 2001, Most 2003). Due to attained temperatures duting metamorphism Most (2003) interpreted these ages as being close to crytalisation.

\section{$D_{2}$ event}

The $S_{1}$ foliation became affected by asymmetric, partly isoclinal or recumbent folds during the $D_{2}$ event (Fig. 3). The kilometre- scale $B_{2}$ folds are associated with small-scale chevron S- and Z- type folds. Fold axes are mainly subhorizontal or slightly plunge towards the NW or SE but in some deviate from this trend. 
A pervasive $S_{2}$ foliation is axial plane with respect to the $B_{2}$ folds and forms the dominant structure of the $\mathrm{D}_{2}$ event (Fig. 3). Crenulation of $\mathrm{S}_{1}$ is well developed in the hinge zones of the $\mathrm{B}_{2}$ folds. Due to intense transposition of $S_{1}$, the $S_{1}$ and $S_{2}$ planes are commonly oriented parallel or subparallel to each other. Like $S_{1}$, the $S_{2}$ foliation dips towards the $S W$ and NE at the western and eastern limbs of the EPZ, respectively. This geometry of the $S_{1}$ and $S_{2}$ fabrics defines a clear dome structure (Fig. 1,2).

$\mathrm{S}_{2}$ is associated with an $\mathrm{L}_{2}$ stretching lineation which is mainly defined by the preferred orientation of quartz, feldspar, sericite, chlorite, chloritoid, and actinolite. In the EPZ and the Loutra-Aridea unit of the Vardar/Axios Zone $\mathrm{L}_{2}$ gently plunges towards the NW or SE. Occasionally, a NE-SW trend is oberserved, which appears to be more common in the tectonically higher metamorphic levels of the Vardar/Axios Zone, e. g., the Peternik and Livadia units, as well as in the KoWPZ (Fig. 2).

Shear sense indicators display a dominant top-to-NW or -WNW transport direction of thrusting. In some cases an opposite, top-to-SE sense of movement is observed. Top-to-SW tectonic transport is mainly recognized in the Peternik and Livadia units of the Vardar/Axios Zone (Fig.1, 2). $\mathrm{D}_{2}$ appaers to correlate with $\mathrm{K} / \mathrm{Ar}$ and $\mathrm{Ar} / \mathrm{Ar}$ ages from syn- $\mathrm{D}_{2}$ white mica between 110 to $95 \mathrm{Ma}$ (Koroneos et al., 1993, Most 2003).

\section{$D_{3}$ event}

$\mathrm{D}_{3}$ structures are characterized by discrete mylonitic shear zones with dynamic recrystalisation of quartz. The $\mathrm{S}_{3}$ mylonitic foliation in general dips to the $\mathrm{NE}$ and the associated well developed $\mathrm{L}_{3}$ stretching lineation plunges downdip (Fig. 2). Shear sense indicators such as S-C fabrics, mica fish, assymetric boudins, and pressure shadows around white mica or feldspar porphyroclasts show a constant downdip (normal) sense of shear. $\mathrm{D}_{3}$ mylonitic shear zones with opposite top-to-SW sense of shear are observed in few cases only. In contrast to the $\mathrm{D}_{1}$ and $\mathrm{D}_{2}$ structures, the $\mathrm{D}_{3}$ structures show rather constant geometry and kinematics. K/Ar ages of fingrained white mica along the $\mathrm{S}_{3}$ mylonitic fabric between 90 and $70 \mathrm{Ma}$ (Koroneos et al 1993, Most 2003) report the $\mathrm{D}_{3}$ evet.

The $\mathrm{D}_{3}$ mylonitic shear zones are very well developed in the Paleozoic sequences of the Vardar/Axios Zone and the KoWPZ overprinting the penetrative $\mathrm{D}_{2}$ structures. According to their geometry and kinematics we interpret the D3 mylonitic shear zones as extensional shear zones. They are probably associated with Late Cretaceous basin formation and the sedimentation of Late Cretaceous limestones and Maastrictian to Paleocene flysch. Neubauer et al.,(1995) showed that Late Cretaceous extension associated with exhumation of metamorphic rocks and formation of the Gosau basin are also a prominent feature in the highest tectonic unit (the Austroalpine mega-unit) in the Eastern Alps.

\section{$D_{4}$ event}

$\mathrm{D}_{4}$ is manifested by open to tight NW-SE trending kink folds, as well as discrete semi-ductile to brittle shear zones indicating constant top-to-SW thrusting (Fig. 2). $\mathrm{B}_{4}$ folds are generally SW-vergent, in few cases NE-vergence is observed due to backthrusting during the $\mathrm{D}_{4}$ event. The folds frequenty fold the $\mathrm{D}_{3}$ shear zones. Locally the folds are associated with a weakly developed crenulation cleavage without significant recrystallization of quartz. The $\mathrm{B}_{4}$ fold axes did not experience parallel to the transport direction but are still oriented perpendicular to the direction of thrusting as it is typical of a brittle environment of deformation. A penetrative cleavage is also missing. $\mathrm{D}_{4}$ occurred at lower temperatures and thus in a more shallow crustal level than the previous events.

$\mathrm{D}_{4}$ structures are mainly exposed in the Vardar/Axios Zone but also occur in the KoWPZ and the EPZ. During $\mathrm{D}_{4}$ the metamorphic rocks of the Vardar/ Axios Zone overthrust the Maistrichtian/Paleocene flysch of the Late Cretaceous basins causing a local low grade dynamic recrystallisation of 
white mica and quartz. K/Ar ages of finegrained sericite of the flysch are ranged between 65 to 50Ma (Most, 2003).

\section{$D_{5}$ event}

Brittle low angle shear zones with normal displacement are formed during the $\mathrm{D}_{5}$ event. They cut all previous structures and juxtapose rocks of higher structural levels against rocks of lower tectonic units. Near Agios Athanasios in the Greek part of the study area the Triassic-Jurassic marbles of the EPZ are directly overlying a Late Paleozoic granite along such a shear zone, cutting out a thick metamorphic sequence of gneisses and schists. The NW contact between EPZ and KoWPZ in FYROM has been reworked by a such a D5 shear zone juxtaposing the low grade metamorphic, Paleozoic sequences of the KoWPZ against the Tr-J EPZ marbles cutting out the KoWPZ gneisses and schists (Fig. 4). Omission of several lithologic units is frequently observed along the entire contact between the EPZ marbles and the underlying units. However, the complete sequence is also preserved in some plases. Continuous sedimentation from the underlying metasediments to the Triassic EPZ carbonates is recognized in a few cases, showing the existence of a Permo-Triassic sequence. Meta-ryolites intercalations inbetween these metasediments evidence for a Permo-Triassic volcanosedimentary series under the Triassic-Jurassic EPZ marbles (Figs 1,4).

$\mathrm{D}_{5}$ shear zones are best recognized in granites and orthogneisses of the Pelagonian nappes as well as in the Vardar/Axios Zone rocks. They are characterized by ultracataclastic rocks. The narrow and discrete shear zones mostly dip towards the SW. Sense of shear is generally downdip (Figs 2, 3). In some cases a strike-slip sense of displacement along the fault planes is observed. For the $\mathrm{D}_{5}$ event (normal shear zones and faults) an age between Late Eocene and beginning Miocene is suggested.

\section{$D_{6}$ event}

$\mathrm{D}_{6}$ structures overprint all older structures and represent the final deformational stage of the orogen. They are high-angle dip-slip to oblique-slip normal and strike-slip faults related to the NeogeneQuaternary basins development in the study area (Figs 2,4).

Many of the $\mathrm{D}_{6}$ faults produce significant tectonostratigraphic gaps juxtaposing higher tectonic units against lower ones. As an example, the E-W to ESE-WNW trending high-angle normal faults along the southern edge of the EPZ schists and gneisses cut their marble cover and the overlying Late Cretaceous to Paleocene limestones and flysch (Fig. 2).

Some of the $\mathrm{D}_{6}$ faults show recent activity, often associated with impressive fault escarpments as, e.g., the ca. ENE-WSW trending fault along the northern margin of the Almopias basin (Fig. 2, Pavlides et al., 1990).

\section{Relationships between deformation and metamorphism}

Metamorphic conditions were calculated from mineral assemblages with syn-kinematic growth with respect to the tectonometamorphic events, as well as with the Tweeq method (Bermann 1991), the garnet-biotite (Ferry and Spear 1978), the garnet-muscovite (Hynes and Forest 1988), the garnetchlorite (Grambing 1990), the muscovite-paragonite (Blencoe et al., 1994), the chloritoid-chlorite (Vidal et al., 1999), and the chlorite (Zang and Fyfe 1995) geothermometers, and the phengite component geobarometer (Massonne and Schreyer 1987). Amphibole and biotite compositions were also used to estimate the P-T conditions (Laird et al., 1984, Schreurs 1985). Mineral chemical analyses were carried out using a JEOV 8900 Superprobe electron microprobe in the Institute of Geosciences of the University of Tübingen. 


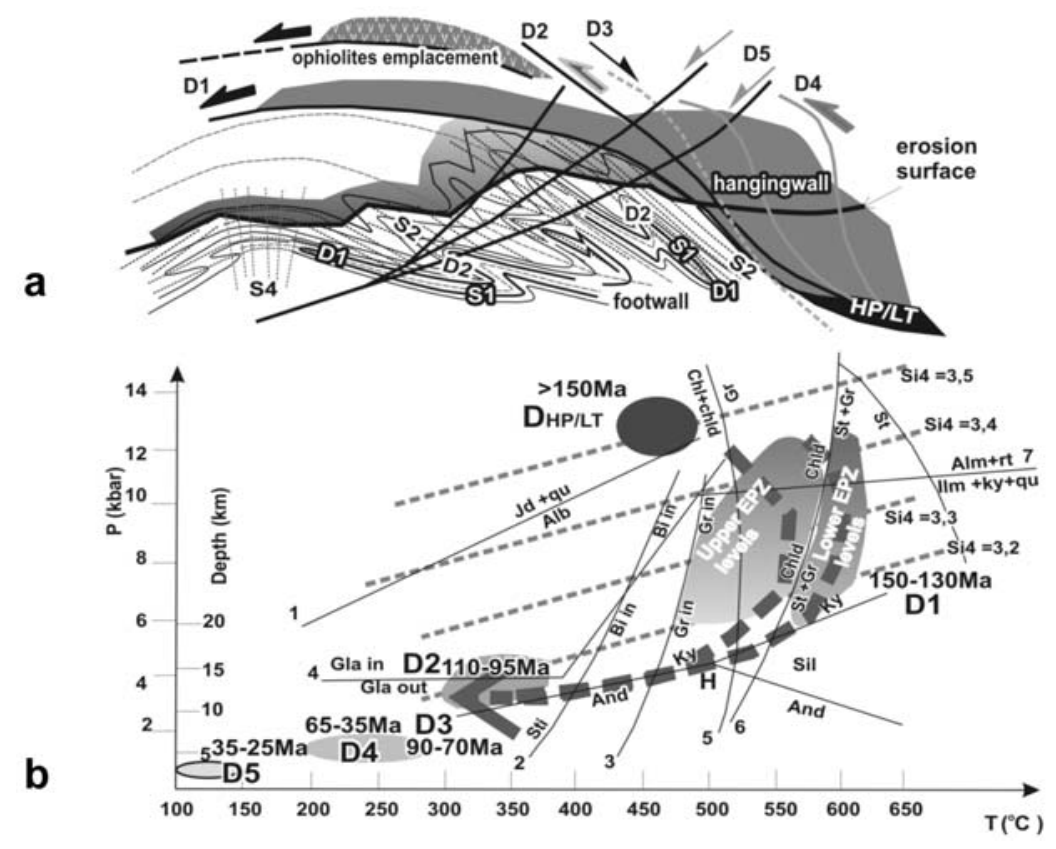

Fig. 3: a. Geometry and kinematics of deformation, b. P-T metamorphic conditions during the several stages of alpine deformation in the study area.

\section{HP event}

The occurrence of phengite, glaucophane, barroisitic hornblende, and rutile in the amphibolites, gneisses, and schists along the western, northern, and eastern tectonic boundary of the EPZ testifies to the existence of a HP event (Fig. 2,4). Sodic pyroxene has been found in the boundary zone between EPZ and Vardar/Axios Zone (Majer and Mason 1983).

Phengitic white mica with maximum 3.5 Si atoms per formula unit (apfu) from a glaucophane schist tectonically above the EPZ marble cover near Skopje (Fig. 3) indicates a minimum pressure of 12.5 $\mathrm{kb}$ for the $\mathrm{D}_{\mathrm{HP}}$ (blueschist facies) event (phengite barometer after Massonne and Schreyer 1987), assuming a temperature of $450-500^{\circ} \mathrm{C}$ (Most 2003).

\section{$D_{1}$ event}

The critical syn- $\mathrm{D}_{1}$ mineral assemblages of the EPZ domal structure used for the thermobarometric investigations are as follows. The metapelites are characterized by garnet, white mica, biotite, chlorite, chloritoid, quartz, plagioclase, ilmenite, sphene, kyanite, and epidote. Staurolite appears in the lower structural levels only. Chloritoid and rutile (as a relict HP mineral) are often included in garnet porphyroblasts showing in some cases a well-developed internal foliation. Rutile is often replaced by ilmenite. The amphibolites contain green amphibole, garnet, white mica, epidote, plagioclase, and biotite.

In the upper tectonostratigraphic levels of the EPZ the calculated temperatures range from $450^{\circ}$ to $580^{\circ} \mathrm{C}$ for a pressure of $10 \mathrm{~kb}$. In the lower levels the temperatures vary between $520^{\circ}$ and $620^{\circ} \mathrm{C}$ for the same pressure. The pressures calculated with the Tweeq method range between 8 and 12.5 $\mathrm{kb}$. The Si content of the syn- $\mathrm{D}_{1}$ white micas varies between 3.2 and 3.4 apfu in average. This indi- 


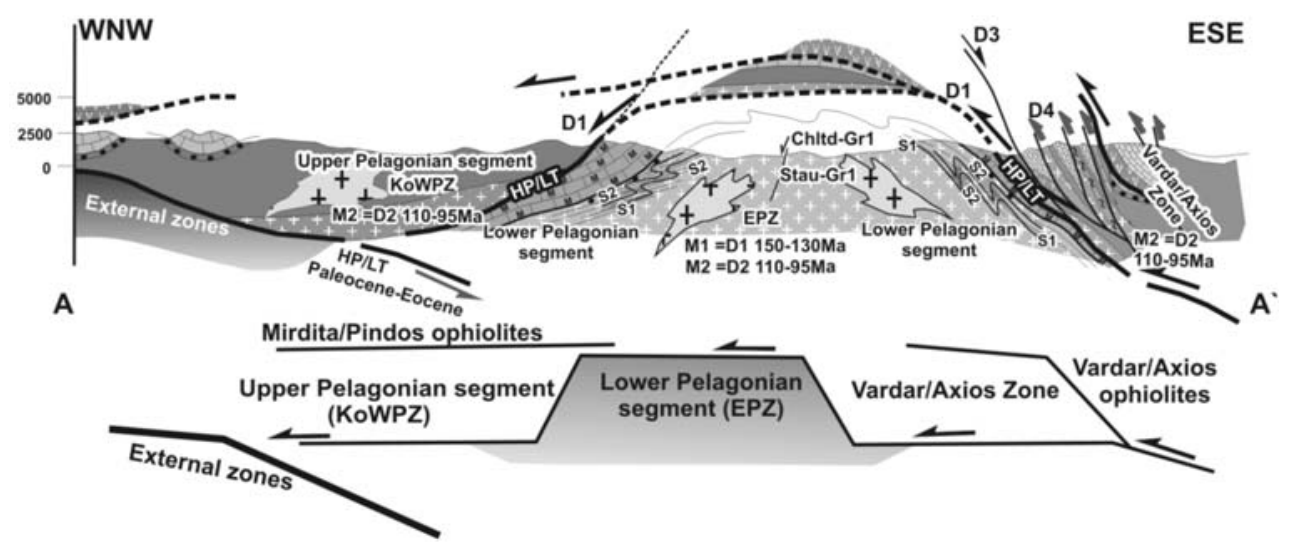

Fig. 4: Cross-section through the Pelagonian nape pile and Vardar/Axios zone.

cates minimum pressures from about 6 to $10 \mathrm{~kb}$ for the estimated temperatures (Fig. 3). The decreasing Si content from 3.36 to 3.1 apfu from core to rim in syn- $\mathrm{D}_{1}$ white mica is ascribed to decreasing pressure during mineral growth.

The changing composition from core to rim of garnet porphyroblasts reflects a change in temperatures during their evolution (Spear et al., 1990). Increasing $\mathrm{X}_{\mathrm{Alm}}$ and the $\mathrm{Mg} /(\mathrm{Mg}+\mathrm{Fe})$ ratio as well as decreasing $\mathrm{X}_{\mathrm{Sps}}$ suggest prograde temperature conditions. Amphibole compositions plot close to the oligoclase isograd in the diagram of Laird et al., (1984). Ti (0.03-0.06 apfu) and $\mathrm{Al}^{\mathrm{VI}}(0.4-0.6)$ contents in biotite of the lower structural levels point to low to medium amphibolite facies conditions $\left(\mathrm{T}=520^{\circ}\right.$ to $600^{\circ} \mathrm{C}$ ) (Table II, Schreurs 1985$)$.

$\mathrm{D}_{2}$ event

The syn- $\mathrm{D}_{1}$ greenschist to amphibolite facies mineral assemblages suffered retrograde, lower greenschist facies overprint during the $\mathrm{D}_{2}$ event, especially well developed in the higher levels of the EPZ. Sericite, actinolite, chlorite, ilmenite, sphene, epidote, and quartz form the critical syn- $\mathrm{D}_{2}$ mineral paragenesis. Replacement of $\mathrm{D}_{1}$ minerals is observed: of biotite and garnet by chlorite and of white mica by sericite in the metapelitic rocks, as well as of hornblende by actinolite and chlorite in the amphibolites. Using the chlorite thermometer on syn- $\mathrm{D}_{2}$ chlorites we estimated a temperature range between $280^{\circ}$ to $380^{\circ} \mathrm{C}$ assuming low-pressure conditions of ca. $4-5 \mathrm{~kb}$ (Fig. 3).

\section{Younger events}

The low-grade metamorphic mylonites to ultramylonites belonging to the $\mathrm{D}_{3}$ event are characterized by the dynamic recrystallization of quartz, quartz ribbons, and a strong lattice preferred orientation of quartz. Feldspar clasts may be broken and show subgrain formation. They are embedded in a dynamically recrystallized quartz and sericite matrix. A well developed S-C fabric is shown by the orientation of quartz and mica. Dynamic recrystalisation of quartz and white mica or chlorite is locally observed along the $\mathrm{D} 4$ thrust faults and $\mathrm{D}_{5}$ extensional low angle shear zones and related shear bands.

\section{Discussion of the geodynamic evolution - conclusions}

Our detailed structural and petrological data combined with geochronological investigation concerning the northern Pelagonian nappe pile and the neighbouring VardarAxios Zone in northern 
Greece and FYROM allows us to constrain the geometry and kinematics of deformation, as well as the structural evolution during the Alpine orogeny.

According to our study, the Pelagonian nappe system in northern Greece and FYROM can be divided into two distinct tectonostratigraphic segments, the footwall (EPZ) and the hangingwall (KoWPZ) Pelagonian segments. The KoWPZ is rooted between EPZ and Vardar/Axios Zone, where only intensely imbricated remnants of slices are recognized. The Paleozoic sequence and the gneisses and schists of the Vardar/Axios Zone are considered to represent the equivalents of the KoWPZ, the connection being eroded in the Pelagonian dome structure (Figs 1, 2, 4).

This scenario proves the duplication of the Pelagonian sequence due to Early Jurassic to Early Cretaceous nappe stacking towards WNW to NW ( $\mathrm{D}_{\mathrm{HP}}$ and $\mathrm{D}_{1}$ event; Figs 3 , 4). It can explain the described high grade metamorphism of the footwall segment of the EPZ that was overthrusted of the thick cover of the hangingwall segment of the KoWPZ. Nappe stacking was related to plate convergence and intraoceanic subduction in the Vardar/Axios Zone. Intraoceanic obduction started around 180-170 Ma (Early to Middle Jurassic) as reported by Ar/Ar dating of metamorphic soles and geologic evidence (Roddick et al., 1979, Spray and Roddick 1980, Sharp and Robertson 2006, Gawlick et al., 2008).

Radiolaritic sequences with olistolites, slides and mass flows, described as ophiolitic mélanges, are common in the thrust sheets of the Vardar/Axios and the Mirdita/Pindos Zones. They are overlain by obducted oceanic lithosphere emplaced during the nappe stacking process (Figs 1, 4, Vergely 1984, Brown and Robertson 2004, Sharp and Robertson 2006, Gawlick et al., 2008).

An important point for the reconstruction of the structural evolution of the study area are the late Late Jurassic to Early Cretaceous clastic sediments and neritic limestones transgressively overlying the ophiolites providing an upper limit for ophiolite emplacement. They indicate that the ophiolites were emplaced before the end of the Jurassic period (Figs 1,2). D1 thrusting and metamorphism in deeper structural levels occurred almost simultaneously with the early sedimentation of this clastic sedimentary sequence, possibly with coeval crustal extension at the top of the nappe pile (Figs 1, 2, 4).

An equivalent sequence of neritic limestones and clastic sediments, the Munella series, is recognized further to the west in Albania, where it seals the Mirdita ophiolitic nappe stack (Gawlick et al., 2008). The Mirdita ophiolites overlie the Triassic-Jurassic carbonate cover of the KoWPZ (Sallo and Dilek 2003, Gawlick et al 2008) (Figs 2, 4).

Plate convergence, thrusting and closure of the Vardar/Axios ocean continued during Aptian to Albian time (ca. 110 to $95 \mathrm{Ma}$ ) with the same kinematics as during the $\mathrm{D}_{1}$ event (D2 event: Figs 1,2). Apart from the main WNW to NW-ward nappe transport the described scattering of $D_{1}$ and $D_{2}$ senses of movement may be attributed to strain partitioning and inhomogeneous deformation or to overprinting and rotation during younger tectonic events. Opposite sense of shear can also be produced due at overturned fold limbs and parasitic small-scale drag folds or by a coaxial component of strain as suggested by the occurrence of abundant symmetric structures such as symmetric boudins and symmetrically elongated clasts. SW-ward sense of movement can be explained by transpressional tectonics in an overall oblique plate convergence regime (Kilias 1991, Most 2003, Vamvaka et al., 2006).

$\mathrm{D}_{1}$ and $\mathrm{D}_{2}$ nappe stacking was followed by $\mathrm{D}_{3}$ low angle normal, discrete mylonitic shear zones in Late Cretaceous time. They were associated with basin formation and sedimentation of Late Cretaceous neritic limestones and Maastrichtian to Paleocene flysch (Figs 1,2,3). Simultaneously with Late Cretaceous to Paleocene sedimentation on top of the tectonically upper units, thrusting in the tectonically lower and more external (more western) units took place. This thrusting process was associa- 
ted with the internal high-pressure metamorphic belt (Fig. 4, Schermer 1993, Kilias et al., 1991). Schermer (1993) relates the formation of the internal HP belt to intra-continental subduction.

The doming of the present antiformal structure of the footwall Pelagonian segment (EPZ) was probably the result of $\mathrm{D}_{4}$ shortening. $\mathrm{D}_{4}$ is related to continuous subduction of continental crust beneath the tectonic lower part of the Pelagonian nappe and the creation of the internal HP belt in the Olympos-Ossa area (Kilias et al., 1991, Schermer 1993), on Evvia island (Xypolias et al., 2003), and in the Cyclades (Lister et al., 1984.) (Fig. 1). $\mathrm{D}_{4}$ is also responsible for the final W- to WSW-ward emplacement of the Internal Hellenides upon the External Hellenides in Eocene-Oligocene time. This means that, from the Late Cretaceous to the Eocene there was a continuous period of deformation prograding from the tectonic top to the tectonic bottom and associated with nappe stacking and HP metamorphism.

Detailed discussion and analysis of paleogeographic settings for the evolution of one or more ocean basins in the Hellenides is outside of the aim of our study. Nevertheless, we like to point out that the suture zone between External and Internal Hellenides is free of ophiolites and all the Pelagonian nappe pile between External Hellenides and the basal ophiolite nappe is continental in origin. Futrhermore, the main NW to WNW directed thrusting during D1 and D2 events, as documented here, indicates that the ophiolitic nappes on top of the Pelagonian nappes should be rooted in the Vardar/Axios ocean basin to the east of the Pelagonian continent. Ophiolite emplacement was consistently towards the west (Figs 3,4). All this suggests that there was no oceanic realm between External and Internal Hellenides and the Pelagonian continental block was not separated from the External Hellenides by an oceanic lithosphere during Alpine orogeny. Therefore, we do not see an independent Pindos Ocean neither in Triassic nor in Jurassic period.

The same scenario is documented in Albania, where the large Mirdita ophiolites nappes to the west of the KoWPZ are far-traveled parts of the Vardar/Axios (Neotethys) ocean, brought into its present position by $\mathrm{W}$-ward thrusting (Gawlick et al., 2008).

Deformation continued during Oligocene to Early Miocene time $\left(\mathrm{D}_{5}\right)$. In higher structural levels of the Pelagonian nappes and the Vardar/Axios Zone brittle conditions prevailed and created cataclasites and ultracataclasites in low-angle extensional shear zones. Simultaneous ductile deformation with mylonites and a constant top-to-the-SW normal sense of shear associated with subhorizontal extension is reported in tectonic deeper levels of the Pelagonian nappe near its contact to the underlying External Hellenides (Kilias et al., 1991, Sfeikos et al., 1991, Schermer 1993). This process is related to Oligocene/Miocene collapse of the Pelagonian nappe pile, tectonic thinning, and unroofing and exhumation of tectonically deeper levels of the External Hellenides (e.g., OlymposOssa window). W- to SW-directed thrusting towards the foreland and the most external parts of the Hellenides continued during this period (Sfeikos et al., 1991, Kilias et al., 1991, Schermer 1993).

From Miocene to present time high-angle normal to oblique-normal faults $\left(D_{6}\right)$ affected all units. This extensional event was responsible for the formation of the Neogene basins and steered the unroofing history of the region.

\section{References}

Arsovski, M. and Dumurdzanov, N., 1984. Recent findings of the structure of the Pelagonian antidinorium and its relation with the Rhodopean and Serbian Macedonian Massif. Geologica Macedonica, $2,15-22$.

Avgerinas, A., Kilias, A., Koroneos, A., Mountrakis, D., Frisch, W., Dunkl, I. and Most, T., 2001. Cretaceous 
structural evolution of the Pelagonian crystalline in Western Voras Mt. (Macedonia, Northern Greece). Bulletin of Geological Society of Greece, 34, 129-136.

Berman, R.G., 1991. Thermobarometry using multiequilibrium calculations: A new technique with petrological applications. Canadian Mineralogist, 29, 833-855

Blencoe, J.G., Guidotti, C. V. and Sassi F.P., 1994. The paragonite-muscovite solvus: II. Numerical geothermometers for natural, quasibinary paragonitemuscovite pairs. Geochim Cosmochim Acta, 58, 2277-2288.

Brown, S.A.M. and Robertson, A.H.F., 2004. Evidence for the Neotethys ocean rooted in the Vardar zone: evidence from the Voras Mountains, NW Greece. Tectonophysics, 381, 143-173.

Catthelineau, M., 1998. Cation site occupancy in chlorites and illites as a function of temperature. Clay Minerals 23, 471-485.

Dinter, A.D., and Royden, L., 1993. Late Cenozoic extension in Northeastern Greece: Strymon Valley detachment and Rhodope metamorphic core complex. Geology, 21, 45-48.

Doutsos, T., Piper, G., Boronkay, K. and Koukouvelas, I., 1993. Kinematics of the Central Hellenides. Tectonics, 12, 936-953.

Ferry, J.M. and Spear, F.S., 1978. Experimental calibration of the partitioning of Fe and Mg between biotite and garnet. Contributions to Mineralogy and Petrology, 66, 113-117.

Gawlick, H.J., Frisch, W., Hoxha, L., Dumitrica, P., Krystyn, L., Lein, R., Missoni, S. and Schlagintweit, F., 2008. Mirdita zone ophiolites and associated sediments in Albania reveal Neothethys Ocean origin. International Journal of Earth Sciences, 94, 865-881.

Geleos, A., Pamoni-Papaioannou, F., Tsaila-Monopolis, S., Turneek, D. and Joakim, Chr., 1994. Upper Jurassic -Lower Cretaceous "molassic type" sedimentation in the western part of Almopia subzone, Loutra Aridea unit (Northern Greece). Bulletin of Geological Society of Greece, 31, 171-184.

Grambling, A.J., 1990. Internaly-consistent geothermometry and $\mathrm{H} 2 \mathrm{O}$ barometry in metamorphic rocks: the axample garnet-chlorite-quartz. Contributions to Mineralogy and Petrology, 105, 617-628.

Hynes, A. and Forest, R.C., 1988. Empirical garnet-muscovite geothermometry in low-grade petapelites, Selwyn Range (Canadian Rockies). Journal of Metamorphic Geology, 6, 297-309.

Jacobshagen, V., Duerr, F., Kockel, K., Kopp, K.O., Kowalczyk, G., Berckhemer, H. and Buttner, D., 1978. Structure and geodynamic evolution of the Aegean region. In: H. Cloos, D. Roeder. and K. Schmidt (eds), Alps, Apennines, Hellenides. E. Schweizerbart sche Verlagsbuchhandlung, Stuttgart, pp. 537-564.

Kilias, A., 1991. Transpressive Tecktonik in den zentralen Helleniden. Aenderung der Translationpfade durch die Transgression Nord-Zentral Griechenland). Neues Jahrbuch fuer Geologie und Palaeontologie Monatshefte, 5, 291-306.

Kilias, A., Fassulas, Ch., Priniotakis, M., Frisch, W. and Sfeikos, A., 1991. Deformation and HP/LT metamorphic conditions at the tectonic window of Kranea W. Thessaly, N. Greece). Zeitschrift der Deutschen Geologischen Gesellschaft, 142, 87-96.

Kilias, A., Falalakis, G. and Mountrakis, D., 1999. GretaceousTertiary structures and Kinematics of the Serbomacedonian metamorphic rocks and their relation to the exhumation of the Hellenic Hinterland Macedonia, Greece). International Journal of Earth Sciences, 88, 513-531.

Koroneos, A., Christofides, G., Del Moro, A., and Kilias, A., 1993. Rb-Sr geochronology and geochemical aspects of the Eastern Varnountas plutonite (NW Macedonia, Greece). Neues Jahrbuch fuer Mineralogische Abhandlungen, 165, 297-315.

Laird, J., Lamphere, M.A., and Albee, A.L., 1984. Distribution of Ordovician and Devonian metamorphism in mafic and pelitic schists from northern Vermont. American Journal of Sciences, 284, 376-413. 
Lister, G.S., Banga, G. and Feenstra, A., 1984. Metamorphic core complex of Cordilleran type in the Cyclades, Aegean Sea, Greece. Geology, 12, 221-225.

Majer, V. and Mason, R., 1983. High pressure metamorphism between the Pelagonian Massif and Vardar Ophiolite belt, Yugoslavia. Mineralogical Magazine, 47, 139-141.

Massonne, H.J., and Schreyer, W., 1987. Phengite geobarometry based on the limiting assemblage with K-feldspar, phlogopite and quartz. Contributions to Mineralogy and Petrology, 96, 212-224.

Medwenitsch, W., 1956. Zur Geologie Vardarisch-Makedoniens (Jugoslawien), zum Problem der Pelagoniden. Oestereichische Akademie der Wissenschaften, Sitzungsberichte der mathematisch naturwissenschaftlichen Klasse, Abteilung 1, 165, 397-473.

Mercier, J., 1968. Etude géologique des zones Hellénides en Macèdoine centrale Grece). Annale Géologique de Pays Hellénique, 20, 17-92.

Most, T., 2003. Geodynamic evolution of the Eastern Pelagonian zone in Northwestern Greece and the republic of Macedonia. PhD Thesis, University of Tuebingen, Tuebingen, 195 pp.

Most, T., Frisch, W., Dunk1, I., Kadosa, B., Boev, B., Avgerinas A. and Kilias, A., 2001. Geochronological and structural investigation of the Northern Pelagonian crystalline zone. Constraints from K/Ar and zirkon and apatite fission track dating. Bulletin of Geological Society of Greece, 34, 91-95.

Mountrakis, D. 1986. The Pelagonian zone in Greece: A polyphase deformed fragment of the Cimmerian continent and its role in the geotectonic evolution of the Eastern Mediterranean. Journal of Geology, 94, 335-347.

Neubauer, F.,. Dallmeyer, R.D, Dunkl, I. and Schirnik, D., 1995. Late Cretaceous exhumation of the metamorphic Gleinalm dome, Eastern Alps: kinematics, cooling history and sedimentary response in a sinistral wrench corridor. Tectonophysics, 242, 79-98.

Pavlides, S., Mountrakis, D., Kilias, A., and Tranos, M., 1990. The role of strikeslip movements in the extensional area of the northern Aegean Greece). Annale Tectonique, 4, 196-211.

Rassios, A.H.E. and Moores, E.M., 2006. Heterogeneous mantle complex, crustal processes, and obduction kinematics in a unifield Pinods-Vourinos ophiolitic slab. In: A.H.F. Robertson and D. Mountrakis (eds), Tectonic Development of the Eastern Mediterranean region. Geological Society of London, Special Publication, 260, pp. 237-266.

Robertson, A.H.F., Dixon, J.E., Brown S. et al., 1996. Alternative tectonic models for the Late Palaeozoic - Early Tertiary development of Tethys in the Eastern Mediterranean. In: J.E. Dixon and A.H.F. Robertson (eds), The Geological Evolution of the Eastern Mediterranean. Geological Society of London Special Publications, 17, pp. 1-74.

Roddick, J., Cameron, W., and Smith, A.G., 1979. PermoTriassic and Jurassic ArAr ages from Greek ophiolites and associated rocks. Nature, 279, 788-790.

Schermer, R.E., 1993. Geometry and kinematics of continental basement deformation during the Alpine orogeny, Mt. Olympos region, Greece. Journal of Structural Geology, 15, 571-591.

Schreurs, J., 1985. Prograde metamorphism of metapelites garnetbiotit thermometry and prograde changes of biotite chemistry, in high grade rocks of west Unsimae, southwest Finland. Lithos, 18, 69-80.

Sfeikos, A., Boehringer, Ch., Frisch, W., Kilias, A. and Ratschbacher, L., 1991. Kinematics of Pelagonian nappes in the Kranea area, North Thessaly, Greece. Bulletin of Geological Society of Greece, 25, 101-115.

Shallo, M. and Dilek, Y., 2003. Development of the ideas on the origin of Albanian ophiolites. Geological Society of America Bulletin, Special Publication, 373, 351-363.

Sharp, I.R. and Robertson, A.H.F., 2006. Tectonicsedimentary evolution of the western margin of the Mesozoic Vardar Ocean: evidence from the Pelagonian and Almopias zones, northern Greece. In: 
A.H.F. Robertson and D. Mountrakis (eds), Tectonic Development of the Eastern Mediterranean Region. Geological Society of London, Special Publication, 260, pp. 373-412.

Simpson, C. and Schmid, S.M., 1983. An evaluation of criteria to deduce the sense of movement in sheared rocks. Geological Society of America Bulletin, 94, 1281-1288.

Spear, F.S., Hickmott, D.D., and Selverstone, J., 1990. Metamorphic consequences of thrust emplacement. Fall Mountains, New Hampshire. Geological Society of America Bulletin, 102, 1344-1360.

Spray, J.G. and Roddick, J.C., 1980. Petrology and ${ }^{40} \mathrm{Ar} /{ }^{39} \mathrm{Ar}$ geochronology of some Hellenic subophiolitic metamorphic rocks. Contributions to Mineralogy and Petrology, 72, 43-55.

Vergely, P. 1984. Tectoniques des ophiolites dans les Hellénides Internes déformation, métamorphisms et phenomenes sédimentaires) Consequences sur l' èvolution des region Téthysiennes Occidentales. PhD Thesis, Universite de Paris - Sud, Orsay, 560 pp.

Vidal, O., Goffe, B., Bousquet, R., and Parra, T., 1999. Calibration and testing of an empirical chloritoidchlorite Mg-Fe exchange thermometer and thermodynamic data for daphnite. Journal of Metamorphic Geology, 17, 25-39.

Xypolias, P., Kokkalas, S., and Skourlis, K., 2003. Upward extrusion and subsequent transpression as a possible mechanism for the exhumation of HP/LT rocks in Evia Island (Aegean Sea, Greece). Journal of Geodynamics, 35, 303-320.

Yarwood, G.A. and Dixon, J.E., 1977. Lower Gretaceous and younger thrusting in the Pelagonian rocks of the High Pieria, Greece. In: Kallergis (ed). Proceedings of the $6^{\text {th }}$ colloquium on the geology of the Aegean region, Athens, pp. 269-280.

Zang, W. and Fyfe, W.S., 1995. Chloritisation of the hydrothermally altered bedrock at the Igarape Bahia gold deposit, Brazil. Mineralium Deposita, 30, 30-38. 